\title{
Penerapan Model PAIKEM dalam Meningkatkan Hasil Belajar
}

\author{
Abdul Malik \\ Dosen Tetap Universitas Muslim Indonesia \\ abdul.malik@umi.ac.id
}

\begin{abstract}
Abstrak
Penelitian ini merupakan penelitian tindakan kelas yang terdiri dari 2 siklus dan setiap siklus terdiri dari 3 pertemuan, 1 pertemuan untuk evaluasi. Masing-masing siklus terdiri dari kegiatan pelaksanaan yaitu: perencanaan, pelaksanaan, observasi, refleksi bertujuan untuk memperoleh data dan informasi tentang penerapan model PAIKEM bidang studi Alqur'an Hadis dalam meningkatkan hasil belajar siswa kelas VIII B di SMP Cokroaminoto Tamalanrea Makassar. Adapun instrumen penelitian yang dilakukan dilapangan yaitu: observasi langsung, angket tertutup dan tes esay. Penelitian dilaksanakan di kelas VIII B Sekolah Menengah Pertama Cokroaminoto Tamalanrea Makassar dengan jumlah siswa 16 orang. Pengumpulan data dilakukan secara bertahap yang diperoleh dari pengamatan pada saat berlangsungnya proses pembelajaran selama penelitian, dan data dari tes hasil belajar pada tiap siklus. Selanjutnya data dianalisis secara kualitatif, yaitu menjelaskan hasil-hasil tindakan selama proses belajar mengajar, dan secara kuantitatif dengan menggunakan statistik deskriptif yaitu skor rata-rata, tabel frekuensi, nilai minimum, nilai maksimum, dan presentase. Hasil penelitian menunjukan bahwa ada peningkatan hasil belajar siswa dan kualitas pembelajaran ditandai dengan meningkatnya keaktifan siswa dalam pembelajaran sesuai dengan hasil observasi selama tindakan kelas berlangsung dan Nilai rata-rata mulai siklus 1 sampai siklus 2, setelah dianalisis dari hasil penelitian yaitu dari pra siklus $62,18 \%$, atau kriteria tingkat keberhasilan siswa dianggap "Gagal", siklus 1 70,62\%, kriteria tingkat keberhasilan siswa berada pada "Baik", dan siklus II 82,62\%, atau kriteria tingkat keberhasilan siswa berada pada "Sangat Baik".
\end{abstract}

Kata Kunci: Penerapan PAIKEM; Model PAIKEM; Belajar; Hasil Belajar.

\section{Pendahuluan}

Pendidikan merupakan suatu usaha yang dilaksanakan secara sadar dan terencana oleh pemerintah dan masyarakat dalam mengembangkan berbagai kompetensi siswa, baik kognitif, afektif, maupun psikomotor ke arah yang lebih sempurna sehingga dapat meningkatkan kualitas pendidikan nasional. Sejalan dengan hal tersebut, Undang Undan No.20 Tahun 2013 tentang sisdiknans pasal 40 ayat (2) dijelaskan bahwa : pendidik dan tenaga kependidikan berkewajiban menciptakan suasana pendidikan yang bernafas menyenangkan, kreatif, dinamis dan dialogis. Tututan pembelajaran ini sering diterjemahkan dengan PAIKEM yang merupakan singkatan pembelajaran, aktif, inovatif, kreatif, efektif, dan menyenangkan.

Guru juga harus menyadari bahwa, pelaksanaan pendidikan terutama pada pendidikan Alqur'an Hadis di sekolah-sekolah umum, baik pada tingkat sekolah SD, SMP, dan SMA kurang diminati oleh siswa, bahkan hanya dianggap sebatas pelajaran tambahan semata. Fenomena seperti inilah yang ditemukan di sekolah SMP Cokroaminoto Tamalanrea Makassar terjadi, karena guru kurang profesional dalam mendesain pembelajaran Alqur'an Hadis. Selain itu metode ceramah, tanya jawab yang menjadi pilihan utama dalam mengajar bagi guru, sehingga menjadikan siswa mudah merasa jenuh dan bosan dalam belajar karena tidak ada hal yang menyenangkan bagi mereka untuk semangat dalam belajar. Hal itu dibuktikan setelah ulangan akhir semester kelas VIII B pada mata pelajaran Alqur'an Hadis selesai di laksanakan di SMP Cokroaminoto Tamalanrea Makassar, dimana $65 \%$ siswa yang mengikuti ulangan tersebut dinyatakan harus mengulang karena tidak mencapai KKM yang di targetkan oleh guru yang bersangkutan yaitu 70, rata-rata siswa hanya mendapatkan nilai ulangan 65 , bahkan ada yang dibawah angka 65 . Hal inilah yang ditemkan oleh peneliti pada saat melaksnakan observasi di sekolah SMP Cokroaminoto Tamalanrea Makassar. 
Untuk mengatasi berbagai problematika dalam pelaksanaan pembelajaran tentu diperlukan model-model pembelajaran yang dipandang mampu mengatasi kesulitan guru dalam melaksanakan tugas mengajar dan juga kesulitan belajar siswa. PAIKEM berasal dari konsep bahwa pembelajaran harus berpusat pada anak (student-centered learning) dan pembelajaran harus bersifat menyenangkan (learning is fun), agar mereka termotivasi untuk terus belajar sendiri tanpa diperintah dan agar mereka tidak merasa terbebani atau takut.

\section{Tinjauan Pustaka}

\subsection{Hasil Belajar}

Belajar pada hakikatnya merupakan proses perubahan di dalam kepribadian yang merupakan kecakapan, sikap, kebiasaan, dan kepandaian. perubahan ini bersifat menetap dalam tingkah laku yang terjadi sebagai suatu hasil dari latihan atau pengalaman. ${ }^{1}$ Pembelajaran pada hakikatnya adalah suatu proses interaksi antara siswa dengan siswa, siswa dengan sumber belajar dan siswa dengan pendidik. Kegiatan pembelajaran ini akan menjadi bermakna bagi siswa jika dilakukan dalam lingkungan yang nyaman dan memberikan rasa aman bagi siswa.

Proses belajar bersifat individual dan kontekstual, artinya proses belajar terjadi dalam diri individu sesuai dengan perkembangannya dan lingkungannya. Belajar bermakna meaningfull learning merupakan suatu proses dikaitkanya informasi baru pada konsep-konsep relevan yang terdapat dalam struktur kognitif seseorang. Dengan kata lain, belajar akan lebih bermakna jika anak mengalami langsung apa yang dipelajarinya dengan mengaktifkan lebih banyak indra dari pada hanya mendengarkan guru menjelaskan. Hal ini yang harus diketahui dan diperhatikan guru dalam melaksanakan PAIKEM. Hal tersebut adalah sebagai berikut :

a) Memahami sifat yang dimiliki siswa.

b) Mengenal siswa secara perorangan

c) Perilaku siswa dalam pengorganisasian belajar

d) Mengembangkan kemampuan berpikir kritis, kreatif, dan kemampuan memecahkan masalah.

e) Mengembangkan ruang kelas sebagai lingkungan belajar yang menarik.

f) Memanfaatkan lingkungan sebagai sumber belajar

g) Memberikan umpan balik yang baik untuk meningkatkan kegiatan belajar.

h) Membedakan antara aktif fisik dan aktif mental. ${ }^{2}$

\subsection{Faktor yang Mempengaruhi Hasil Belajar}

Hasil belajar dapat dipengaruhi oleh berbagai hal. Hamzah Uno menegaskan bahwa motivasi belajar adalah dorongan internal dan eksternal pada siswa yang sedang belajar sehingga mengadakan perubahan tingkah laku denagan indikator sebagai berikut. ${ }^{3}$ (1) adanya hasrat dan keinginan untuk sukses dan berhasil, (2) adanya dorongan dan kebutuhan dalam belajar, (3) adanya harapan dan cita-cita masa depan, (4) adanya penghargaan dalam kelompok, (5) adanya kegiatan yang menarik dalam belajar, serta (6) adanya lingkungan yang kondusif, sehingga siswa dapat belajar denagan baik.

\subsection{Model PAIKEM}

Terdapat empat aspek yang mempengaruhi model PAIKEM, yaitu pengalaman, komunikasi, interaksi, dan refleksi.

a. Pengalaman. Diaspek pengalaman ini siswa diajarkan untuk dapat belajar mandiri.

b. Komunikasi. Aspek komunikasi ini dapat dilakukan dengan beberapa bentuk, antara lain mengemukakan pendapat, presentasi laporan, dan memajangkan hasil kerja.

c. Interaksi. Aspek interaksi ini dapat di lakukan dengan cara interaksi, tanya jawab, dan saling melempar pertanyaan.

\footnotetext{
${ }^{1}$ Mohamad Syarif Sumantri, Strategi Pembelajaran, (Cet. II ; Jakarta : PT RajaGrafindo Persada, 2016), h. 161

${ }^{2}$ Mohamad Syarif Sumantri, Strategi Pembelajaran, (Cet. II ; Jakarta : PT RajaGrafindo Persada, 2016), h. 130

${ }^{3}$ Mohamad Syarif Sumantri, Strategi Pembelajaran, (Cet. II ; Jakarta : PT RajaGrafindo Persada, 2016), h. 379
} 
d. Refleksi. Dalam aspek ini yang dilakukan adalah memikirkan kembali apa yang telah diperbuat/dipikirkan oleh anak selama mereka belajar. ${ }^{4}$

\section{Metode Penelitian}

Berdasarkan sumber data yang diperoleh, metode penelitian yang digunakan dalam penulisan proposal ini adalah penelitian lapangan (field research) berupa penelitian kualitatif. Sedangkan jenis Penelitian ini yang digunakan yaitu merupakan penelitian tindakan kelas yang mengkaji peningkatan hasil belajar siswa pada bidang studi Alqur'an hadis melalui penerapan model PAIKEM pada siswa kelas VIII B di SMP Cokroaminoto Tamalanrea Makassar. Penelitian tindakan kelas (PTK) dapat di artikan sebagai peristiwa sosial dengan tujuan untuk meningkatkan kualitas tindakan di dalamnya. Dimana dalam proses tersebut mencakup kegiatan yang menimbulkan hubungan antara evaluasi diri dengan profesional.

\subsection{Prosedur penelitian}

Prosedur penelitian sesuai dengan jenis penelitian tindakan kelas. Penelitian tindakan kelas ini menggunakan desain PTK model siklus John Elliott yang terdiri dari dua siklus. Siklus I terdiri dari 2 x pertemuan dengan alokasi waktu 2 x 40 menit. Siklus II terdiri dari 2 x pertemuan dengan alokasi waktu 2 x 40 menit. Pada tiap siklus mencakup tahap-tahap sebagai berikut: 1) perencanaan . 2) pelaksanaan. 3) observasi dan evaluasi 4) dan, refleksi. Keempat langkah yang dikenal dengan istilah Model John Elliot

\section{Siklus I}

a. Perencanaan

b. Pelaksanaan tindakan

c. Observasi dan Evaluasi

d. Refleksi

2. Siklus II

Langkah-langkah yang dilakukan pada siklus ke II merupakan refleksi dari siklus I. Oleh karena itu, langkah-langkah yang dilakukan relatif sama dengan siklus I dengan beberapa perbaikan dan penyempurnaan sesuai dengan kenyataan yang telah ditemukan dilapangan.

\subsection{TeknikPenggumpulan Data}

Teknik penggumpulan data yang digunkan yaitu :

a. Pemberian tes tertulis berupa butir buti soal, tekinik ini digunakan untuk memperoleh data mengenai hasil belajar yang dicapai siswa kelas VIII B SMP Cokroaminoto Tamalanrea Makassar setelah mengikuti pelajaran dengan model PAIKEM.

b. Penyebaran angket, yang bertujuan untuk memperoleh data mengenai persepsi siswa terhadap pembelajaran model PAIKEM yang telah diikutinnya. Angket yang berisi pernyataan tentang keadaan belajar siswa setelah mengikuti pembelajaran diberikan kepada siswa kelas VIII B SMP Cokroaminoto Tamalanrea Makassar.

\subsection{Instrumen penelitian}

Instrumen penelitian adalah alat yang digunakan untuk mengumpulkan data penelitian, instrumen yang akan digunakan dalam penelitian ini adalah :

a. Tes adalah serentetan pertanyaan atau latihan serta latihan alat lain yang digunakan untuk mengukur keterampilan, pengetahuan intelejensi, kemampuan atau bakat yang dimiliki oleh individu atau kelompok. ${ }^{5}$ Tes diberikan pada setiap siswa yang menjadi objek penelitian, yang bertujuan untuk mengumpulkan informasi tentang pemahaman siswa terhadap pembelajaran Alqur'an Hadis. Tes dilaksanakan oleh peneliti kepada siswa kelas VIII B SMP Cokroaminoto Tamalanrea Makassar pada setiap akhir siklus setelah diberikan serangkain tindakan.

b. Observasi

c. Angket

${ }^{4}$ Op.Cit., h. 328

${ }^{5}$ Arifin Gantun, dalam Suharsimi Arikunto, Prosedur Penelitian, (Cet. XV ; Jakarta: PT Bumi Aksara, 2013 ), h. 193 


\subsection{Teknik Analisis Data}

Dalam penelitian ini, peneliti mengumpulkan data dua jenis yaitu data kualitattif dan kuantitatif. Analisis dihitung dengan menggunakan statistik sederhana yaitu :

a. Melalui ulangan atau tes tertulis

Penelitian melakukan penjumlahan nilai yang diperoleh siswa, yang selanjutnya dibagi dengan jumlah siswa yang ada di kelas tersebut sehingga diperoleh rata-rata tes dapat dirumuskan :

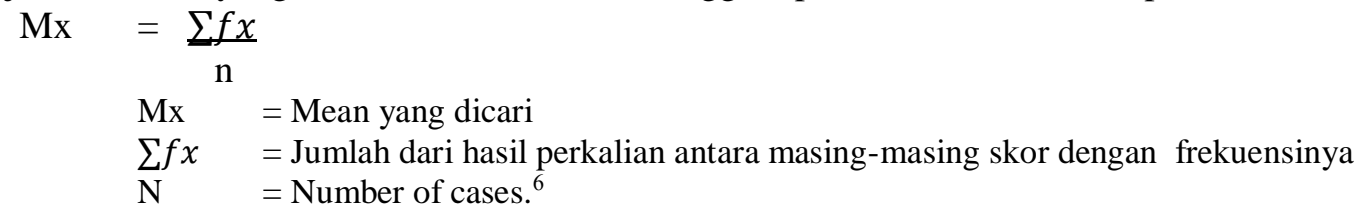

b. Untuk menghitung presentase ketuntasan belajar digunakan rumus

sebagai berikut :

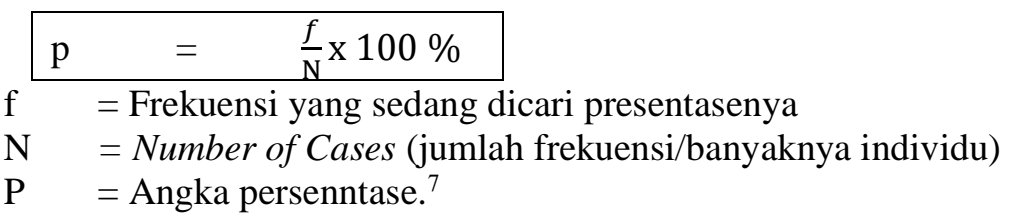

Adapun KKM atau Kriteria Ketuntasan Minimal siswa kelas VIII B SMPCokroaminoto Tamalanrea Makassar pada mata pelajaran pada penelitian ini adalah 75, yang merupakan hasil dari jumalah KKM kompetensi dasar KD dibagi jumlah indikator. Dirumuskan sebagai berikut :

\section{$\sum$ KKM KD $\sum K \mathrm{KD} /$ Indikator \\ Keterangan: \\ $\sum \mathrm{KKM} \mathrm{KD}=$ kriteria keketuntasan minimal per KD}

c. Kategori nilai hasil belajar

\section{Keterangan :}

A = apabial nilai hasil belajar siswa 90-100, maka penelitian ini dikatakan sangat baik.

$\mathrm{B}=$ apabila nilai hasil belajar siswa 80-89, maka penelitian ini dikatakan baik.

$\mathrm{C}=$ apabila nilai hasil belajar siswa 70-79, maka penelitian ini dikatakan cukup baik.

$\mathrm{D}=$ apabila nilai hasil belajar siswa 60-69, maka penelitian ini dikatakan kurang.

$\mathrm{E}=$ apabila nilai hasil belajar siswa $<60$, maka penelitian ini dikatakan sangat kurang. ${ }^{8}$

Penelitian ini dianggap berhasil jika nilai rata-rata hasil belajar siswa berada pada kategori 70-79, dan apa bila hasil rata-rata belajar siswa kelas VIII SMP Cokroaminoto Makassar berada pada kategori 60-69, maka penelitian ini dianggap gagal.

\section{Hasil Penelitian dan Pembahasan}

\subsection{Pra Siklus}

Sebelum melakasanakan tindakan penelitian, maka peneliti menemui kepala sekolah SMP Cokroaminoto Tamalanrea Makassar untuk melakukan koordinasi agar dalam pelaksanaan penelitian dapat berjalan sesuai rencana. Selanjutnya kepala sekolah menyerahkan sepenuhnya kepada guru mata pelajaran Al-qur'an Hadis untuk membicarakan tentang pelaksanaan tindakan penelitian. Pada hari Senin tanggal 10 April 2018 peneliti melakukan observasi kepada siswa kelas VIII B dan peneliti memperoleh data sebagai berikut:

\footnotetext{
${ }^{6}$ Gantun Arif, dalam Anas Sudijono, Statistik Pendidikan, (Cet. XXI ; Jakarta : Rajawali Pers, 2010), h. 85

${ }^{7}$ Ibid., h. 43

${ }^{8}$ http://file.upi.edu/Direktori/FPMIP. Bahan Ajar (Minggu Ke 12) Pengolahan Hasil Penilaian Compatibility Mode, 2010. Diakses Pada Tanggal 25 Oktober 2017.
} 
Tabel 3:

Data Hasil Observasi Siswa Kelas VIII B di SMP Cokroaminoto Tamalanrea Makassar Sebelum Penerapan Model PAIKEM Pada Bidang Studi Al-qur'an Hadis

\begin{tabular}{|c|l|c|c|}
\hline No & \multicolumn{1}{|c|}{ Indikator yang diamati } & $\begin{array}{c}\text { Jumlah } \\
\text { siswa }\end{array}$ & \% \\
\hline 1 & Siswa yang hadir pada saat pembelajaran berlangsung & 16 & $100 \%$ \\
\hline 2 & Siswa memperhatikan penjelasan guru & 7 & $43,75 \%$ \\
\hline 3 & Siswa mengajukan pertanyaan & 1 & $6,25 \%$ \\
\hline 4 & Siswa menjawab pertanyaan & 4 & $25 \%$ \\
\hline 5 & Siswa bekerja sama dengan kelompoknya & 0 & $0 \%$ \\
\hline 6 & Siswa mampu merangkum pembelajaran yang telah berlangsung & 7 & $43,75 \%$ \\
\hline 7 & Siswa suka keluar masuk kelas ketika proses belajar berlangsung & 2 & $12,5 \%$ \\
\hline 8 & $\begin{array}{l}\text { Siswa suka cerita diluar materi yang diajarkan ketika proses belajar } \\
\text { berlangsung }\end{array}$ & 5 & $31,25 \%$ \\
\hline 9 & Siswa kurang mengerti tentang materi yang diajarkan & 11 & $68,75 \%$ \\
\hline 10 & Siswa yang mengerti tentang materi yang diberikan & 5 & $31,25 \%$ \\
\hline
\end{tabular}

Berdasarkan hasil tes yang dilaksanakan oleh peneliti pada observasi awal hasil belajar pada bidang studi Al-qur'an Hadis siswa kelas VIII B SMP Cokroaminoto Tamalanrea Makassar cenderung rendah, oleh karena itu peneliti telah merancang sebuah konsep pembelajaran dengan menggunakan model PAIEM. Penelitian ini merupakan penelitian tindakakan kelas, dimana pelaksanaan tindakan terdiri dari 2 siklus, pada siklus pertama sebanyak 3 kali pertemuan, sehingga dapat diperoleh data hasil belajar siswa kelas VIII B SMP Cokroaminoto Tamalanrea Makassar. Data yang diperoleh dianalisis, dalam bentuk kuantitatif melalui tes yang dilakukan pada tiap akhir siklus. Berikut hasil belajar siswa kelas VIII B.

Tabel 5

Statistik Skor Hasil Belajar Pra Siklus

\begin{tabular}{|c|c|c|}
\hline No & Statistik & Nilai Statistik \\
\hline 1 & Subjek penelitian & 16 \\
\hline 2 & Skor ideal & 80 \\
\hline 3 & Skor maksimum & 100 \\
\hline 4 & Skor Minimun & 70 \\
\hline
\end{tabular}

Peneliti memberi tes awal pada setiap siswa, untuk mengetahui tingkat pemahaman siswa sebelum dilaksanakan tindakan. Sedangkan untuk mencari nilai rata-rata siswa dapat digunakan perhitungan sebagai berikut:

Tabel 6

Perhitungan Untuk Mencari Nilai Mean Tahap Pra Siklus

\begin{tabular}{|c|c|c|}
\hline $\mathbf{X}$ & $\mathbf{F}$ & $\mathbf{F x}$ \\
\hline 40 & 1 & 40 \\
\hline 50 & 3 & 150 \\
\hline 55 & 2 & 110 \\
\hline 60 & 3 & 180 \\
\hline 65 & 3 & 195 \\
\hline 80 & 4 & 320 \\
\hline Total & $\mathrm{N}=16$ & $\sum \mathrm{Fx}=995$ \\
\hline
\end{tabular}

Sumber : Diolah dari hasil tes

$$
\mathrm{M}_{\mathrm{x}}=\frac{\sum F x}{N} \text { atau } \frac{995}{16}=62,18 \%
$$


Apabila skor hasil belajar Al-qur'an Hadis siswa pada prasiklus dikelompokkan kedalam 5 kategori maka diperoleh distribusi frekuensi skor yang ditunjukkan pada tabel berikut:

Tabel 7

Distribusi Frekuensi dan Persentase Skor Hasil Belajar Siswa Pada Tahap Pra Siklus

\begin{tabular}{|c|c|c|c|c|}
\hline No. & Skor & Kualifikasi & Frekuensi & Persentase \\
\hline 1. & $90-100 \%$ & Sangat Baik & 0 & $0 \%$ \\
\hline 2. & $80-89 \%$ & Baik & 4 & $25 \%$ \\
\hline 3. & $70-79 \%$ & Cukup Baik & 0 & $0 \%$ \\
\hline 4. & $60-69 \%$ & Kurang & 6 & $37,5 \%$ \\
\hline 5. & $<60 \%$ & Sangat Kurang & 6 & $37,5 \%$ \\
\hline \multicolumn{7}{|c|}{ Jumlah } & 16 & $100 \%$ \\
\hline
\end{tabular}

\section{Sumber : Diolah dari hasil tes}

Tabel tersebut menunjukkan bahwa hasil belajar bidang studi Al-qur'an Hadis siswa cukup bervariasi, tetapi dari tabel tersebut terlihat siswa yang berada pada kategori sangat kurang yaitu 6 orang atau 37,5\%, kategori kurang yaitu 6 orang atau 37,5\%, kategori cukup baik yaitu 0 (tidak ada) atau $0 \%$, kategori baik yaitu 4 orang atau $25 \%$, dan kategori sangat baik 0 (tidak ada) atau 0 $\%$. Hasil ini disebabkan karena masih kurangnya antusias belajar siswa dalam pembelajaran Alqur'an Hadis, dan peneliti juga belum menerapakan model PAIKEM yang akan digunakan dalam pembelajaran.

Berdasarkan hasil perhitungan tersebut diperoleh rata-rata nilai hasil belajar siswa kelas VIII B SMP Cokroaminoto Tamalanrea Makassar pada prasiklus atau tes awal yaitu 62, $18 \%$ sangat rendah. Untuk lebih efektif dalam proses pembelajar pendidikan Al-kur'an Hadis yaitu dengan menggunakan model PAIKEM dalam meningkatkan hasil belajar siswa kelas VIII B SMP Cokroaminoto Tamalanrea Makassar.

\section{Tabel 8}

Frekuensi dan Persentase Ketuntasan Hasil Belajar Bidang Studi Al-qur'an Hadis Siswa Kelas VIII B SMP Cokrominoto Tamalanrea Makassar

\begin{tabular}{|c|c|c|c|}
\hline No. & Kriteria & Frekuensi & Persentase \\
\hline 1. & Tuntas & 4 & $25 \%$ \\
\hline 2. & Tidak Tuntas & 12 & $75 \%$ \\
\hline \multicolumn{2}{|c|}{ Jumlah } & 16 & $100 \%$ \\
\hline
\end{tabular}

\subsection{Siklus I}

Kegiatan pada siklus I dalam penelitian tindakan kelas ini, meliputi: perencanaan, pelaksanaan tindakan, observasi, dan refleksi. Maka diperoleh gambaran tentang hasil belajar siswa kelas VIII B SMP Cokroaminoto Tamalanrea Makassar. Tes akhir siklus ini diikuti oleh semua siswa kelas VIII B SMP Cokroaminoto Tamalanrea Makassar yang berjumlah 16 orang. Adapun masing-masing kegiatan yaitu sebagai berikut: PAIKEM Dapat Meningkatkan Hasil Belajar Siswa

a. Hasil observasi

Berdasarkan lembar observasi yang dilakukan peneliti pada saat proses pembelajaran berlangsung pada siklus pertama diperoleh hasil sebagai berikut:

1. Pada pertemuan pertama siklus I, proses pembelajaran dengan model PAIKEM. Pada pertemuan ini siswa yang hadir pada saat proses pembelajaran berlangsung 16 orang atau $100 \%$ siswa yang mengikuti dengan cermat peroses pembelajaran. Pada pertemuan ini umumnya siswa yang belum terbiasa dengan model pembelajaran yang digunakan. Namun 
pada pertemuan kedua hingga berakhirnya pertemuan pada siklus I siswa sudah terbiasa dengan model pembelajaran yang digunakan.

2. Siswa memperhatikan penjelasan guru, pada pertemuan pertama hanya 8 orang atau $50 \%$, namaun pada pertemuan selanjutnya meningkat menjadi 10 orang atau $62,5 \%$. Hal ini menunjukkan perhatian siswa dalam belajar meningkat.

3. Siswa mengajukan pertanyaan mengalami peningkatan, hal ini terlihat dari pertemuan pertama hingga pertemuan terakhir siklus I, yaitu 2 orang atau $12,5 \%$ kemudian pertemuan selanjutnya 4 orang atau $25 \%$. Hal ini menunjukkan rasa ingin tahu siswa terhadap pelajaran PendidikanAlku'an Hadis semakin meningkat.

4. Siswa menjawab pertanyaan, mengalami peningkatan. Ini terlihat dari pertemuan pertama hingga pertemuan terakhir siklus I, yaitu 5 orang atau $31,25 \%$, yang kemudian selanjutnya meningkat menjadi 9 orang atau 56,25\%. Hal ini menunjukkan bahwa siswa semangat berkompetisi dalam belajar.

5. Siswa bekerja sama dengan kelompoknya, pada pertemuan pertama siklus I, hanya 12 orang atau $75 \%$ yang kemudian pada pertemuan selanjutnya meningkat menjadi 14 orang atau $87,5 \%$. Hal ini menunjukkan antusias siswa dalam bekerja kelompok dan bisa melakukan kerja sama dengan teman kelompoknya.

6. Siswa mampu merangkum pembelajaran yang telah berlangsung, pada pertemuan pertama siklus I, hanya 9 oranag atau $56,25 \%$ yang kemudian pada pertemuan selanjutnya meningkat menjadi 10 orang atau $62,5 \%$. Hal ini menunjukkan minat belajar siswa mengalami peningkatan.

7. Siswa suka keluar masuk kelas saat proses pembelajaran berlangsung, dari pertemuan pertama samapai pertemuan terakhir siklus I tidak mengalami pengurangan. Pada pertemuan pertama siklus I, terdapat 2 oranag atau 12, $5 \%$ yang kemudian pada pertemuan selanjutnya juga 2 oranag atau $12,5 \%$.

8. Siswa suka cerita diluar materi yang diajarkan ketika proses pelajaran berlangsung, pada pertemuan pertama hanya 3 orang atau $18,75 \%$, namaun pada pertemuan selanjutnya berkurang menjadi 2 orang atau 12,5\%. Hal ini menunjukkan semakin bagusnya model pembelajaran yang digunakan dan minat belajar siswa semakin meningkat.

9. Siswa kurang mengerti tentang materi yang diajarkan, pada pertemuan pertama siklus I berjumlah 9 orang atau 56,25\%, namaunpada pertemuan selanjutnya berkurang menjadi 7 orang atau $43,75 \%$ yang tidak mengerti.

10. Siswa yang mengerti tentang materi yang diberikan, pada pertemuan pertama hanya 10 orang atau $62,5 \%$, namaun pada pertemuan selanjutnya meningkat menjadi 14 orang atau $75 \%$. Hal ini menunjukkan perhatian dan pemahaman siswa dalam belajara pendidikan Agama Islam.

\section{b. Hasil tes siklus I}

Berdasarkan hasil tes yang dilakukan pada siklus I sebagaimana terlihat pada tabel berikut: Pada siklus I pelaksanaan tindakan, masi terdapat beberapa siswa yang belum paham tentang model PAIKEM yang peneliti terapkan sehingga beberapa siswa yang belum tuntas. Berikut ini tabel skor hasil belajar siswa yang dianalisis kedalam nilai statistik yaitu sebagai berikut:

Tabel 12

Statistik Skor Hasil Belajar

\begin{tabular}{|c|c|c|}
\hline No. & Statistik & Nilai Statistik \\
\hline 1. & Subjek Penelitian & 16 \\
\hline 2. & Skor Ideal & 80 \\
\hline 3. & Skor Maksimum & 100 \\
\hline 4. & Skor Minimum & 70 \\
\hline
\end{tabular}


Pada siklus I pelaksanaan tindakan, masi ada beberapa siswa yang belum paham tentang model PAIKEM yang peneliti terapkan sehingga beberapa siswa yang belum tuntas. Berikut ini tabel skor hasil belajar siswa yang dianalisis kedalam nilai statistik yaitu sebagai berikut:

Tabel 13

Perhitungan Untuk Mencari Nilai Mean

\begin{tabular}{|c|c|c|}
\hline $\mathbf{X}$ & $\mathbf{F}$ & $\mathbf{F x}$ \\
\hline 55 & 1 & 55 \\
\hline 60 & 5 & 300 \\
\hline 65 & 3 & 195 \\
\hline 67 & 1 & 67 \\
\hline 70 & 2 & 140 \\
\hline 85 & 1 & 85 \\
\hline 95 & 2 & 190 \\
\hline 98 & 1 & 98 \\
\hline Total & $\mathrm{N}=16$ & $\sum \mathrm{Fx}=1130$ \\
\hline
\end{tabular}

Sumber: Diolah dari hasil tes

$\mathrm{M}_{\mathrm{x}} \quad=\frac{\sum F x}{N}$ atau $\frac{1130}{16}=70,62 \%$

Tabel 14

Distribusi Frekuensi dan Presentase Skor Hasil Belajar Siswa Pada Siklus I

\begin{tabular}{|c|c|c|c|c|}
\hline No. & Skor & Kualifikasi & Frekuensi & Persentase \\
\hline 1. & $90-100 \%$ & Sangat Baik & 3 & $18,75 \%$ \\
\hline 2. & $80-89 \%$ & Baik & 1 & $6,25 \%$ \\
\hline 3. & $70-79 \%$ & Cukup Baik & 2 & $12,5 \%$ \\
\hline 4. & $60-69 \%$ & Kurang & 9 & $56,25 \%$ \\
\hline 5. & $<60 \%$ & Sangat Kurang & 1 & $6,25 \%$ \\
\hline \multicolumn{2}{|c|}{ Jumlah } & 16 & $100 \%$ \\
\hline
\end{tabular}

Sumber : Diolah dari hasil tes

Tabel tersebut menunjukkan bahwa hasil belajar Pendidikan Al-kur'an Hadis siswa cukup bervariasi dan terlihat tidak ada siswa yang berada pada kategori sangat kurang yaitu 1 orang atau $6,25 \%$, kategori kurang yaitu 9 orang atau 56,25\%, kategori cukup baik yaitu 2 orang atau 12,5\%, kategori baik yaitu 1 orang atau $6,25 \%$, dan kategori sangat baik yaitu 3 orang atau 18,75\%. Hal ini disebabkan karena masih kurang antusias siswa dalam proses pembelajaran Pendidikan Alkur'an Hadis. Apabila hasil belajar Pendidikan Al-kur'an Hadis siswa pada siklus I dianalisis, maka persentase ketuntasan belajar siswa pada siklus II dapat dilihat pada tabel berikut:

Tabel 15

Deskripsi Ketuntasan Belajar

\begin{tabular}{|c|c|c|c|}
\hline No. & Kriteria & Frekuensi & Presentase \\
\hline 1 & Tuntas & 6 & $37,5 \%$ \\
\hline 2 & Tidak Tuntas & 10 & $62,5 \%$ \\
\hline \multicolumn{2}{|c|}{ Jumlah } & 16 & $100 \%$ \\
\hline
\end{tabular}

Sumber : Diolah dari hasil tes 
Data tersebut menunjukkan bahwa siklus I persentase ketuntasan siswa kategori tuntas sebesar $25 \%$ yaitu 4 dari 16 siswa. Sedangkan dalam kategori tidak tuntas sebesar $75 \%$ yaitu 12 dari 16 siswa.

Berdasarkan hasil penelitian yang dilakukan pada siklus I terhadap siswa kelas VIII B SMP Cokroaminoto Tamalanrea Makassar, perolehan nilai hasil ketuntasan belajar siswa masih di bawah standar maka dalam hal ini akan dilanjutkan perbaikan pada siklus II dengan Metode pembelajaran yang sama.

c. Refleksi

1. Pada siklus I, pertemuan pertama penelitian berlangsung cukup baik, namun masih belum tercipta pembelajaran yang efektif, kerena siswa masih malu-malu dan rasa takut untuk aktif menjawab pertanyaan.

2. Siswa masih canggung dalam proses pembelajaran model PAIKEM.

3. Siswa masih belum terbiasa menerapkan model PAIKEM dalam pembelajaran

4. Masih ada beberapa siswa yang kurang mendengarkan dan memperhatikan ketika peneliti menjelaskan materi dan pada saat model PAIKEM berlangsung, namun peneliti dapat memberi motivasi sehingga proses belajar berjalan dengan baik.

\subsection{Siklus II}

Siklus II ini merupakan lanjutan dari siklus I, dari hasil tes pada siklus II kita bisa melihat bagaimana peningkatan hasil belajar siswa kelas VIII B SMP Cokroaminoto Tamalanrea Makassar terhadap mata pelajaran Pendidikan Al-kur'an HAdis setelah diadakan Model PAIKEM pada materi pokok Mengutamakan kejujuran dan menegakkan keadilan. Tes akhir siklus ini diikuti oleh semua siswa kelas VIII B SMP Cokroaminoto Tamalanrea Makassar yang berjumlah 16 orang.

\section{Perencanaan}

Perencanaan siklus II sesuai pelaksanaan siklus pertama dengan menambahkan atau mengurangi bagian-bagian yang dianggap perlu berdasarkan hasil refleksi pada siklus pertama. Tindakan siklus kedua dilaksanakan dua kali pertemuan, dengan perincian yaitu 1 kali pertemuan untuk proses pembelajaran dan 1 kali pertemuan untuk proses pembelajaran sekaligus hasil tes belajar. Pertemuan pertama pada hari senin, 20 Agustus 2018, pertemuan kedua sekaligus tes hasil belajar pada hari senin, 27 Agustus 2018.

\section{Pelaksanaan tindakan}

Pelaksanaan tindakan yang dilakukan pada siklus II adalah mengulangi kembali tahap-tahap pada siklus I sambil mengadakan perbaikan atau penyempurnaan sesuai hasil yang diperoleh pada siklus II. Tahap dalam pelaksanaan tindakan pada siklus II sebenarnya sama saja pada tahap pelaksanaan tindakan pada siklus I, hanya saja ada beberapa perbedaan yaitu terletak pada materi yang disampaikan, yaitu membahas tentang mengutamakan kejujuran dan menegakkan keadilan. Dan terdapat pula perbedaan pada jawaban yang disampaikan oleh masing-masing kelompok yaitu pada pertemuan pertama kelompok 1 menjawab dengan benar, kelompok 2 salah dalam menjawab pertanyaan. Pertanyaan selanjutnya "jelaskan pengertian jujur", kelompok 3 menjawab dengan benar kelompok 4 berhasil menjawab dengan sempurna karena dapat menjawab pertanyaan dari kelompok 2. Setelah kegiatan diskusi, maka peneliti memberikan motivasi dan penguatan, langkah selanjutnya peneliti memberikan penilaian model PAIKEM dan tes kepada seluruh siswa.

\section{Hasil observasi}

Berdasarkan lembar observasi yang dilakukan peneliti pada saat proses pembelajaran berlangsung pada siklus kedua diperoleh hasil sebagai berikut:

a. Pada pertemuan III banyak siswa yang hadir pada saat pembelajaran berlangsung berjumlah 16 orang siswa dari 16 siswa keseluruhan atau $100 \%$, sedangkan pada pertemuan IV jumlah siswa yang hadir sama dengan pertemuan III yaitu 16 orang atau $100 \%$.

b. Siswa memperhatikan penjelasan guru pada pertemuan III terdapat 12 orang siswa atau $75 \%$, kemudian meningkat menjadi 14 orang atau $87,5 \%$ pada pertemuan IV. 
c. Siswa yang mengajukan pertanyaan berjumlah 5 orang atau $31,25 \%$ pada pertemuan III, meningkat menjadi 6 orang siswa atau $37,5 \%$ pada pertemuan IV.

d. Siswa menjawab pertanyaan berjumlah 10 orang siswa atau $62,5 \%$ pada pertemuan ke III, meningkat menjadi 11 orang siswa atau $68,75 \%$ pada pertemuan ke IV.

e. Siswa bekerja sama dengan kelompoknya berjumlah 15 orang siswa atau 93,75\% pada pertemuan ke III, meningkat menjadi 15 orang siswa atau 93,75 \% pada pertemuan ke IV.

f. Siswa mampu merangkum pelajaran yang telah berlangsung berjumlah 11 orang siswa atau $68,75 \%$ pada pertemuan ke III, mengalami peningkatan yaitu 12 orang siswa atau $75 \%$ pada pertemuan ke IV.

g. Siswa suka keluar masuk kelas saat proses belajar berlangsung berjumlah 2 orang siswa atau $12,5 \%$ pada pertemuan III, dan mengalami peningkatan (tidak ada) orang siswa atau $0 \%$ siswa keluar masuk pada pertemuan ke IV. Ini menunjukkan bahwa semua siswa sudah tertarik dengan metode pembelajaran yang diterapkan

h. Siswa suka cerita diluar materi yang diajarkan ketika proses belajar berlangsung berjumlah 1 orang siswa atau $6,25 \%$ pada pertemuan ke III, pada pertemuan ke IV berkurang menjadi 0 orang siswa atau $0 \%$. Hal ini menandakan berkurangnya siswa yang suka bicara selain materi yang dijelaskan di dalam kelas.

i. Siswa kurang mengerti tentang materi yang diajarkan berjumlah 6 orang siswa atau 37,5\% pada pertemuan III, pada pertemuan ke IV berkurang menjadi 4 orang atau $25 \%$ siswa. Hal ini menunjukkan bahwa metode Talking Stick berhasil mengurangi siswa yang tidak mengerti dengan materi Pendidikan Agama Islam yang diajarkan.

j. Siswa yang mengerti tentang materi yang diberikan berjumlah 13 orang siswa atau 81,25\% pada pertemuan III, pada pertemuan ke IV meningkat menjadi 14 orang siswa atau 87,5\%. Hal ini menunjukkan bahwa siswa kelas VIII B SMP Cokroaminoto Tamalanrea Makassar mengerti dengan materi yang diajarkan.

4. Hasil tes siklus II

Berdasarkan hasil tes yang dilakukan pada siklus II sebagaimana terlihat pada tabel berikut:

Tabel 19

Skor Hasil Belajar

\begin{tabular}{|c|c|c|}
\hline No. & Statistik & $\begin{array}{c}\text { Nilai } \\
\text { Statistik }\end{array}$ \\
\hline 1. & Subjek Penelitian & 16 \\
\hline 2. & Skor Ideal & 100 \\
\hline 3. & Skor Maksimum & 70 \\
\hline 4. & Skor Minimum & 62 \\
\hline 5. & Rata - Rata & 82,62 \\
\hline
\end{tabular}

Pada siklus II peneliti memberi tes pada setiap siswa. Nilai diperoleh siswa dikomulatifkan dengan teman kelompoknya. Sedangkan untuk mengetahui nilai rata-rata siswa dapat menggunakan rumus sebagai berikut:

Tabel 20

Perhitungan Untuk Mencari Nilai Mean

\begin{tabular}{|c|c|c|}
\hline $\mathbf{X}$ & $\mathbf{F}$ & $\mathbf{F x}$ \\
\hline 62 & 1 & 62 \\
\hline 69 & 1 & 69 \\
\hline 73 & 1 & 73 \\
\hline 75 & 2 & 150 \\
\hline 80 & 2 & 160 \\
\hline 82 & 1 & 82 \\
\hline
\end{tabular}




\begin{tabular}{|c|c|c|}
\hline 84 & 1 & 84 \\
\hline 86 & 1 & 86 \\
\hline 88 & 3 & 264 \\
\hline 94 & 1 & 94 \\
\hline 98 & 1 & 98 \\
\hline 100 & 1 & 100 \\
\hline Total & $\mathrm{N}=16$ & $\sum \mathrm{Fx}=1322$ \\
\hline
\end{tabular}

\section{Sumber: Diolah dari hasil tes}

\section{$\mathrm{M}_{\mathrm{x}}=\frac{\sum F x}{N}$ atau $\frac{1322}{16}=82,62 \%$}

Apabila skor hasil belajar Al-kur'an Hadis siswa pada siklus II di kelompokkan kedalam 5 kategori maka diperoleh distribusi frekuensi skor yang ditunjukkan pada tabel berikut ini:

Tabel 21

Distribusi Frekuensi dan Presentase Skor Hasil Belajar Siswa Pada Siklus II

\begin{tabular}{|c|c|c|c|c|}
\hline No. & Skor & Kualifikasi & Frekuensi & Persentase \\
\hline 1. & $90-100 \%$ & Sangat Baik & 3 & $18,75 \%$ \\
\hline 2. & $80-89 \%$ & Baik & 8 & $50 \%$ \\
\hline 3. & $70-79 \%$ & Cukup Baik & 3 & $18,75 \%$ \\
\hline 4. & $60-69 \%$ & Kurang & 2 & $12,5 \%$ \\
\hline 5. & $<60 \%$ & Sangat Kurang & 0 & $0 \%$ \\
\hline \multicolumn{2}{|c|}{ Jumlah } & 16 & $100 \%$ \\
\hline
\end{tabular}

\section{Sumber: Diolah dari hasil tes}

Tabel tersebut menunjukkan bahwa hasil belajar Pendidikan Al-kur'an Haids siswa cukup bervariasi dan mengalami peningkatan dengan prolehan nilai siswa yang berada pada kategori sangat kurang 0 orang atau $0 \%$, pada kategori kurang ada 2 orang siswa atau $12,5 \%$, dan pada kategori cukup baik terdapat 3 orang siswa atau $18,75 \%$, sedangkan kategori baik 8 orang atau 50 $\%$, dan kategori sangat baik 3 orang atau 18,75 \%. Apabila hasil belajar Pendidikan Al-kur'an Hadis siswa pada siklus II dianalisis, maka persentase ketuntasan belajar siswa pada siklus II dapat dilihat pada table berikut:

Tabel 22

Deskripsi Ketuntasan Belajar

\begin{tabular}{|c|c|c|c|}
\hline No. & Kriteria & Frekuensi & Presentase \\
\hline 1 & Tuntas & 14 & $87,5 \%$ \\
\hline 2 & Tidak Tuntas & 2 & $12,5 \%$ \\
\hline \multicolumn{2}{|c|}{ Jumlah } & 16 & $100 \%$ \\
\hline
\end{tabular}

Sumber :Diolah dari hasil tes

Tabel tersebut menunjukkan bahwa siklus II persentase ketuntasan siswa sebesar 87,5 \% yaitu 14 dari 16 siswa termasuk kategori tuntas dan $12,5 \%$ yaitu 2 dari 16 siswa termasuk dalam kategori tidak tuntas.

Berdasarkan tabel tersebut, hal ini menunjukkan bahwa masih ada siswa yang memperoleh nilai dibawah nilai minimum 70 . Akan tetapi nilai rata-rata kelas juga mengalami peningkatan dari siklus I sebesar 70,62 menjadi 82,62 pada siklus II. Dari hasil penelitian yang dilakukan mulai dari siklus I sampai pada siklus II yang menunjukkan terjadinya peningkatan sebesar 27,75\% nilai perolehan rata-rata hasil belajar terhadap ketuntasan hasil belajar siswa melalui model PAIKEM 
Selanjutnya untuk melihat perkembangan ketuntasan hasil belajar bidang studi Al-qur'an Hadis pada siswa kelas VIII B SMP Cokroaminoto Tamalanrea Makassar yang dilakukan pada siklus II dapat dilihat pada grafik berikut:

Tabel 23

Nilai Siswa Pada Prasiklus, Siklus I, dan Siklus II

\begin{tabular}{|c|l|c|c|c|}
\hline No & \multicolumn{1}{|c|}{ Nama } & Prasiklus & Siklus I & Siklus II \\
\hline 1 & Reynaldhi. K & 40 & 55 & 80 \\
\hline 2 & Muh. AsrullahAchmad & 60 & 65 & 75 \\
\hline 3 & Wawan Kurniawan & 65 & 67 & 73 \\
\hline 4 & Nur Ru'yatullah Arsyad & 80 & 95 & 98 \\
\hline 5 & Andi Nurul Fitra & 80 & 95 & 94 \\
\hline 6 & Amiruddin & 50 & 60 & 82 \\
\hline 7 & Muammar Kadafi & 60 & 65 & 84 \\
\hline 8 & Ahmad Nurul Sabil & 55 & 60 & 88 \\
\hline 9 & Siti Jamaisa & 80 & 85 & 88 \\
\hline 10 & Muhammad Risal Rifaldi & 55 & 60 & 80 \\
\hline 11 & Vira & 50 & 60 & 75 \\
\hline 12 & Saldi & 50 & 60 & 62 \\
\hline 13 & Nur Azizah & 80 & 98 & 100 \\
\hline 14 & Muh. Adhrian & 65 & 70 & 86 \\
\hline 15 & Oki Dwi Putra & 60 & 65 & 69 \\
\hline 16 & Muh. Ma'ruf & 65 & 70 & 88 \\
\hline Total & & 695 & 1130 & 1322 \\
\hline Rata-rata & 62,18 & 70,62 & 82,62 \\
\hline
\end{tabular}

Sumber: Diolah dari hasil tes siswa

Pada tabel di atas dapat kita lihat peningkatan prestasi hasil beljar siswa kelas VIII B SMP Cokroaminot Tamalantea Makassar berdasarkan hasil pehitungan tersebut diperoleh rata-rata nilai hasil pada prasiklus / tes awal yaitu 62,18, pada siklus I berdasarkan hasil perhiutungan di peroleh nilai rata-rata yaitu 70,62, dan pada siklus II berdasarkan hasil perhitungan di peroleh nilai rata-rata yaitu 82,62. Selanjutnya untuk melihat perkembangan hasil belajar Al-kur'an hadis siswa kelas VIII B SMP Cokroaminoto Tamalanrea Makassar yang dilakukan pada prasiklus, siklus I, dan siklus II dapat dilihat pada grafik berikut ini

Perbandingan Nilai Rata-rata Bidan Studi Al-qur'an Hadis Prasiklus, Siklus I, dan Siklus II

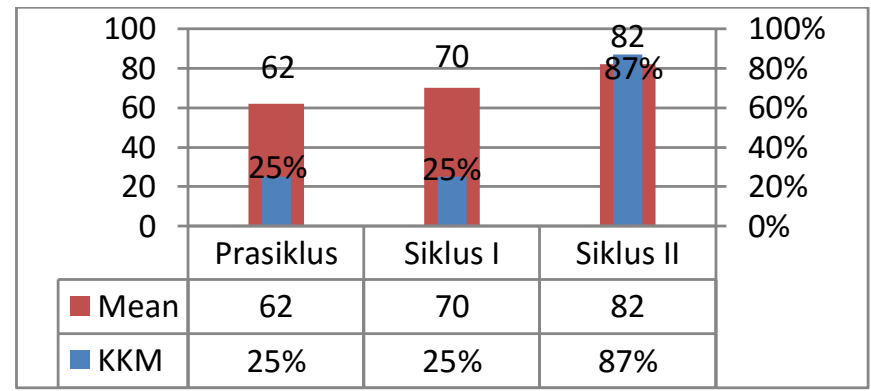




\section{Kesimpulan} berikut :

Berdasarkan hasil penelitian pada bab IV, maka peneliti dapat menyimpulkan sebagai

1. Penerapan Model PAIKEM dalam meningkatkan hasil belajar siswa pada Bidang Studi Alqur'an Hadis kelas VIII B di SMP Cokroaminoto Tamalanrea Makassar, dimana siswa dibagi kedalam beberapa kelompok yang saling bekerja sama materi yang diberikan oleh guru dan membuat kondisi belajar siswa menjadi aktif dan menyenangkan yang sangat bermanfaat bagi mereka, dimana siswa lebih memahami dan mengerti dengan model pembelajaran yang diterapkan.

2. Penerapan Model PAIKEM dapat meningkatkan hasi belajar siswa, hal ini dilihat dari hasil belajar siswa pada setiap siklus yang mengalami peningkatan. Adapun hasil yang didapatkan, mempunyai perbandingan nilai rata-rata persentase, pada prasiklus jumlah rata-rata nilai siswa 62 dengan tingkat ketuntasan 25\% dari 16 siswa, atau tingkat keberhasilan siswa dianggap "Gagal" karena tidak memenuhi kriteria ketuntasan minimum (KKM), siklus I jumlah rata-rata nilai siswa 70 dengan tingkat ketuntasan $37 \%$ dari 16 siswa atau tingkat keberhasilan siswa dianggap "Cukup Baik", akan tetapi belum memenuhi tingkat ketuntasan klasikal yaitu 75\% dari jumlah siswa. dan pada siklus II jumlah rata-rata nilai siswa 98 dengan tingkat ketuntasan 87\% dari 16 siswa atau kriteria tingkat keberhasilan siswa dianggap "Baik". Karena telah mencapai standar KKM yaitu nilai 70 dengan tingkat ketuntasan $75 \%$ dari jumlah siswa. 


\section{DAFTAR PUSTAKA}

Al-Imam Ibnu Qudamah Al-Makdisi, Mukhtasar Minhajul Qashidin, Cet. IX ; 3 Jakarta $\quad$ : Almaktab Al-Islamia, 2000

Departemen Agama RI, Al-Qur'an dan Terjemahan, Cet. I ; Jakarta Selatan : Cahaya Qur'an, 2011

Daryanto, Inovasi Pembelajaran Efektif, Cet. I ; Bandung : Yrama Widya, 2013

Gantun Arif, dalam Anas Sudijono, Statistik Pendidikan, Cet. XXI ; Jakarta : Rajawali Pers, 2010.

Hamzah B. Uno dan Nurdin Mohamd, Belajar dengan Pendekatan PAILKEM, Cet. VII ; Bumi Aksara, 2017

http : // file.upi.edu / Direktori /FPMIP. Bahan ajar (Minggu ke 12) Pengolahan Hasil Penilaian Compatibility Model, 2010.

Intan Nur, Pengaruh Kretivitas Guru Al-Qur'an Hadis Terhadap Prestasi Dan Minat Belajar Peserta Didik, Makassar : UIN ALAUDDIN, 2017.

Kurniasih Imas dan Sani Berlin, Penelitian Tindakan Kelas, Kata Penah, 2014 Mohamad Syarif Sumantri, Strategi Pembelajaran, Cet. II ; Jakarta : PT RajaGrafindo Persada, 2016

Muhammad Rusydi Ikhsan, Penerapan Pembelajaran Aktif, Inovatif, Kreatif, Efektif, dan Menyeangkan, SMPN 1Parigi Kabupaten Gowa, 2014

Munzeir Suparto, Ilmu Hadis, Cet. IX ; Jakarta : PT Raja Grafindo, 2014

Masitoh, Upaya Meningkatkan Hasil Belajar Siswa Dengan Menggunakan Metode Inquiry Learning Pada Mata Pelajaran Al-Qur'an Hadis Materi Hukum Bacaan Idgham Bilaghunnah, Idgham Bighunnah Dan Ikhfa Di Kelas VIII MTs Ali-Imron Medan, 2017

Nurhasana Bakhtiar, Pendidikan Agama Islam, Cet. I ; Yogyakarta : Aswaja Presindo, 2013

Rusman, Model Model Pembelajaran Mengembangkan Profesionalisme Guru, Cet. VI ; PT Raja Grafindo Persda, 2013

Subana, at, All, Statistik Pendidikan, Cet. X ; Bandung : Pustaka Setia, 2000

Sugiyono, Metode Penelitian Pendidikan, Cet. XXV ; Bandung: Alfabeta, 2017

Suharisimi Arikunto, Prosedur Penelitian, Cet. XV ; Jakrta: PT Bumi Aksara, 2013

Syahidan Nurdin, dalam Darmiwati, Inovasi Pembelajaran Efektif, Ed. VI ; Bandung: Yrama Widya, 2013.

Tim Penyusun Kamus pusat Bahasa, Kamus Besar Bahasa Indonesia, Cet. VI; $\quad$ Jakarta: Gramedia, 2008

Trianto, Mendesain Pembelajaran Inovatif-Progresif, Cet. II ; Jakarta : Kencan Prenada Media Group, 2013 